\title{
ESTUDIOS
}

\section{EQUÍVOCA QUINTAESENCIA. ALQUIMIA ESPIRITUAL Y MONEDA FALSA EN LA ESPAÑA DEL SIGLO XVI*}

\author{
María Tausiet \\ CCHS-CSIC, Madrid
}

\section{RESUMEN}

Una de las principales obsesiones de la Edad Moderna consistió en determinar las nociones de verdadero y falso para aplicarlas a los distintos campos del saber y, de ese modo, fundamentar la separación entre lo lícito y lo prohibido. Dicha tendencia iba a afectar especialmente a los terrenos de la religión y la ciencia, haciéndose necesario distinguir no sólo verdaderos y falsos espíritus, reliquias o milagros, sino también verdaderos y falsos astrólogos y alquimistas. Situada a caballo entre el idealismo y el materialismo, la alquimia ejemplificaba especialmente dichas tensiones, como se comprobará a través del proceso incoado en 1593 contra un fraile del monasterio jerónimo de Santa Engracia de Zaragoza, a quien su prior acusó de fabricar «plata de humo y joyas de trasgos».

PALABRAS CLAVE: Alquimia. Fraude. Falsificación. Platero. Duendes. Trasgos. Monasterio de Santa Engracia. Moneda falsa.

\section{EQUIVOCAL QUINTESSENCE. SPIRITUAL ALCHEMY AND COUNTERFEIT} MONEY IN $16^{\mathrm{TH}}-$ CENTURY SPAIN

\section{ABSTRACT}

One of the main obsessions of the Early Modern Era was that of determining the notions of true and false, in order to apply them to various fields of knowledge and thus establish the divide between the lawful and the unlawful. This trend was to have a particular impact on the fields of re-

* Una primera versión de este artículo apareció en LÓPEZ PÉREZ, M., KAHN, O. y REYBuEno, M. (eds.) (2010), Chymia: Science and Nature in Medieval and Early Modern Europe, Cambridge, Cambridge Scholars Publishing. 
ligion and science, where it became necessary to distinguish not only between true and false spirits, relics or miracles, but also between genuine and fake astrologers and alchemists. Situated in the middle ground between idealism and materialism, alchemy was prime territory for such tensions, as was demonstrated by a trial held in 1593 at the Jeronymite monastery of Santa Engracia in Saragossa, whose prior accused a friar of making «silver out of smoke and jewels from goblins».

KEY WORDS: Alchemy. Fraud. Counterfeit. Silversmith. Goblins. Trasgos. Santa Engracia Monastery. Counterfeit coin.

Este testigo le respondió con colera, diziendo que se fuese con la gracia de Dios y con su plata de humo y joyas de trasgos ${ }^{1}$.

Una de las principales obsesiones de la Edad Moderna consistió en determinar las nociones de verdadero y falso para aplicarlas a los distintos campos del saber y, de ese modo, fundamentar la separación entre lo lícito y lo prohibido. Esta tendencia iba a afectar especialmente a los terrenos de la religión y la ciencia, haciéndose necesario distinguir no solo verdaderos y falsos espíritus, reliquias o milagros, sino también verdaderos y falsos astrólogos y alquimistas. Situada a caballo entre el idealismo y el materialismo, la alquimia ejemplificaba al máximo estas tensiones, ya que frente a los auténticos «filósofos», dedicados a la vertiente espiritual de la ciencia hermética, estaba comúnmente aceptado que el único propósito de la inmensa mayoría de sus practicantes no era otro que enriquecerse.

Dicho discurso dualista y maniqueo pretendía justificar el noble arte de la alquimia asociándola a una exigua minoría de iniciados a quienes, no obstante, resultaba extremadamente difícil localizar en la práctica, salvo a través de la memoria contenida en sus obras, escritas mucho tiempo atrás. Lo cierto es que día a día proliferaban las voces de condena contra un sinnúmero de charlatanes pseudoalquimistas, acusados de estafar a muchos inocentes con la promesa de transformar cualquier metal en oro o plata puros mediante sus trucos y recetas. Entre los siglos XIII y XVII, los ataques contra los alquimistas impostores acabaron por convertirse en un leitmotiv tanto en la literatura como en la legislación europeas. De forma paralela, durante estos siglos la utopía alquímica y el sueño de alcanzar la piedra filosofal fueron generalizándose cada vez más entre los miembros de todas las clases sociales ${ }^{2}$.

1 Proceso contra fray Juan de Santa Ana (Zaragoza, 1593-1596), Archivo Diocesano de Zaragoza (ADZ), S/C, vol. I, fol. 264r.

2 Fuera de España, algunos de los personajes literarios que mejor ejemplifican el tópico del falso alquimista aparecen en los Cuentos de Canterbury de Geoffrey Chaucer (Canon's 
Debido al secreto ${ }^{3}$ con que debían realizarse las operaciones alquímicas, los testimonios de primera mano acerca de una ciencia caracterizada por su ocultismo no resultan muy abundantes. Más escasos aún son los documentos que atestiguan su práctica entre los menos favorecidos ${ }^{4}$. En ese sentido, el opúsculo dedicado en 1593 a Felipe II por el irlandés Richard Stanyhurst para ayudar al rey a distinguir a los falsos de los verdaderos alquimistas representa una valiosa fuente acerca de la práctica del arte fuera de los ámbitos estrictamente cortesanos. El breve tratado encabezaba su largo título con una metáfora inspirada, que hacía referencia a la capacidad de la piedra de toque para probar la autenticidad del oro. De ahí que el librito se presentara a sí mismo como: «El toque de alquimia, en el qual se declaran los verdaderos y falsos efectos del arte, y como se conosceran las falsas practicas de los engañadores y haraneros vagamundos» ${ }^{5}$.

Yeoman's Tale, ca. 1380) y en la obra The alchemist (ca. 1610), del dramaturgo Ben Jonson. En España, es célebre el enxiemplo XX de El conde Lucanor (1330-1335), de Don Juan Manuel, titulado «De lo que contesçio a un rey con un omne que dixo quel faria alquimia», donde el rey acaba siendo estafado por un astuto charlatán. Asimismo, son muchas las menciones a los falsos alquimistas en la legislación española (por ejemplo, en Las Partidas, VII, 7), así como los tratados españoles contra los engaños de la alquimia (Engaños de la alquimia, Contra los alquimistas, etc.) Véanse READ, J. (1957), Through Alchemy to Chemistry, Londres, G. Bell \& Sons (trad. esp., Por la alquimia a la química, Madrid, Aguilar, 1960); GARCíA FONT, J. (1995), Historia de la alquimia en España (1 ${ }^{\mathrm{a}}$ ed., 1976), Barcelona, MRA; MuÑOZ CALvo, S. (1977), Inquisición y ciencia en la España moderna, Madrid, Editora Nacional; y Caro Baroja, J. (1993), Jardín de flores raras, Barcelona, Seix Barral, pp. 67-88.

3 Aunque en latín «arcanum» significa «secreto» en un sentido amplio, en el mundo de la alquimia se entendía como «conocimiento secreto» asociado a los procedimientos del arte. De ahí que con frecuencia el lenguaje de los alquimistas se denominara «lenguaje arcano» y la alquimia en general, «disciplina arcana». Véase CROSLAND, M.P. (1962), Historical Studies in the Language of Chemistry, Londres, Heinemann, p. 101.

4 Sobre los llamados «secretos naturales» y sus asociaciones con la alquimia, véanse EAmon, W. (1994), Science and the Secrets of Nature. Books of Secrets in Medieval and Early Modern Culture, Princeton, Princeton University Press; y NEWMAN, W.R. y GRAFTON, A. (coords.), (2001), Secrets of Nature: Astrology and Alchemy in Early Modern Europe, Cambridge (Massachusetts), The MIT Press.

5 Biblioteca Nacional de Madrid (BNE), ms. 2058, 95. T. V, fols. 248r-257v. Puede consultarse una transcripción completa del tratado en TAUSIET, M. (1994), El toque de alquimia: un método casi infalible dedicado a Felipe II por Richard Stanyhurst. En CAMPOS, J. y FERNÁNDEZ DE SEVILlA, F. (coords.), La ciencia en el Monasterio del Escorial, San Lorenzo del Escorial, EDES, pp. 525-558. Sobre el interés de Felipe II en la alquimia, véanse: LóPEZ PIÑERo, J.M. (1979), Ciencia y técnica en la sociedad española de los siglos XVI y XVII, Barcelona, Labor; Goodman, D. (1988), Poder y penuria. Gobierno, tecnología y sociedad en 
Los indicios para reconocer a tales embusteros aparecían resumidos en cuatro: inmoralidad, ignorancia, pobreza y utilización de materiales extravagantes. En consecuencia, sólo los buenos cristianos, versados en el arte, con un nivel económico suficiente como para sobrevivir dignamente sin tener que recurrir a la estafa, y dispuestos a obrar con sustancias comunes, resultaban dignos de confianza. El prototipo del alquimista tramposo, errante o vagabundo, contrastaba, por tanto, con el del sabio sosegado que, sin ser apenas notado, dedicaba sus esfuerzos desinteresados a la consecución del opus magnum.

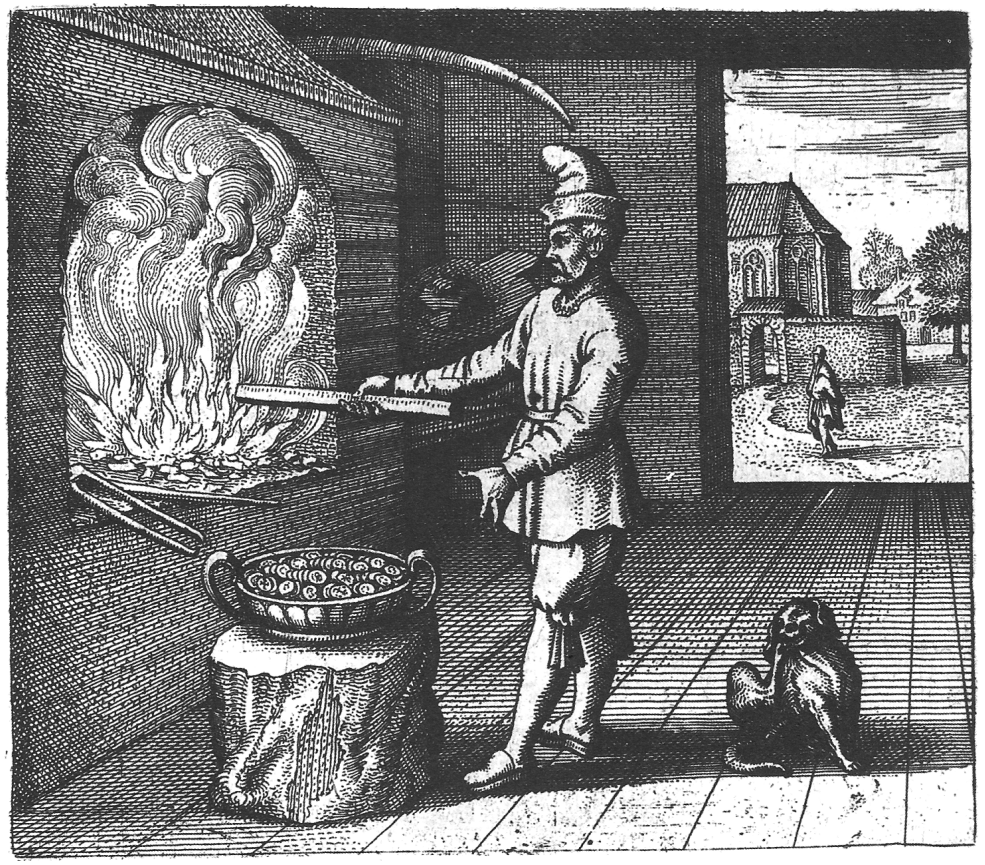

Ignire ignis amat, non aurificare sed aurum («El fuego gusta de prender fuego, pero el oro de hacer oro no»). El oro vulgar es inútil en la Obra a no ser que se transforme en Oro filosófico. En Michael Maier, Atalanta fugiens, Fráncfort, 1618. Emblema XVIII.

la España de Felipe II, Madrid, Alianza; Puerto Sarmiento, J.F., Alegre Pérez, M.E., Rey Bueno, M. y LóPez PÉrez, M. (coords.) (2001), Los hijos de Hermes. Alquimia y Espagiria en la terapéutica española moderna, Madrid, Aurora Borealis; PUERTO SARMIENTO, F.J. (2003), La leyenda verde: naturaleza, sanidad y ciencia en la corte de Felipe II (1527-1598), Valladolid, Consejería de Educación y Cultura. 


\section{ALQUIMISTA ANTES QUE FRAILE}

Nadie más cercano, en principio, al perfil del alquimista virtuoso que fray Juan de Santa Ana, a quien conocemos gracias a las pesquisas realizadas por diversos organismos judiciales entre 1593 y 1596 para tratar de descubrir la auténtica naturaleza de sus actividades. Fray Juan vivía en el monasterio de Santa Engracia de Zaragoza, dedicado a la oración, y también al estudio y a la práctica de la alquimia. Ocupaba una celda individual, en la que había instalado varios fogariles, alimentados con carbón, y en ella guardaba los instrumentos necesarios para su arte (crisoles, redomas, morteros, fuelles, tenazas, alcohol, estaño, etc.), además de un buen número de libros impresos y manuscritos.

Según su propio testimonio, su intención no era otra que fabricar la piedra filosofal y, asimismo, ayudar a remediar las necesidades del monasterio y de otras muchas iglesias pobres, donde faltaban cálices e imágenes de plata que él era capaz de elaborar a partir de metales menos nobles, como el estaño:

Leyendo en Aristoteles y Santo Tomas [...] le parezio que era juego de pocas tablas probar a hazer la piedra filosofal. Si con ella se saliese, bien; y si no, también. Pues saliendo con ella pudiera hazer, con licencia de su Magestad, obras piadosissimas, como son calizes para pueblos pobres que no los tienen, sino de estaño, et multa alia simila ${ }^{6}$.

La creencia en la posibilidad de fabricar la piedra filosofal era compartida por la mayoría de sus contemporáneos, entre los que se contaban muchos representantes del estamento eclesiástico. No es de extrañar, por tanto, que en un primer momento, cuando el fraile solicitó permiso para labrar «unas ymagencillas de estaño o alquimia [...] y para tener fogariles y carbon y lo que huviesse menester ${ }^{7}$, el prior del monasterio le concediese licencia de inmediato. No obstante, a la vista de las muchas horas que fray Juan pasaba encerrado en su taller, y ante el continuo trasiego de plateros y alquimistas que no dejaban de entrar al monasterio, el prior fue cambiando de opinión, hasta que, pareciéndole «que era mucha ocupacion para religioso que habia de acudir al coro y al altar [...] rogo al dicho fray Juan que no entendiese en dichas cosas» ${ }^{8}$. Al mismo tiempo, ordenó al portero del monasterio que en lo sucesivo impidiera pasar a los plateros o alquimistas que constantemente acudían a verlo.

6 Proceso contra fray Juan de Santa Ana, vol. I, fol. 60r.

7 Proceso contra fray Juan de Santa Ana, vol. I, fol. 263v.

8 Proceso contra fray Juan de Santa Ana, vol. I, fol. 60r. 
Pese a ello, fray Juan continuó con sus actividades y visitas, lo que supuso que tanto él como el fraile portero fueran reprendidos en varias ocasiones ante el capítulo. Lejos de obedecer al prior, fray Juan insistía una y otra vez en decirle que cómo le prohibía algo que era

cosa tan probechosa para las almas y aun para la casa y monasterio de Sant Bartholome de Lupiana, donde era profeso, y desta de Santa Engracia, que tanta necesidad tenian de candeleros, relicarios y otras cosas para el culto divino? .

Ante tanta reiteración, en cierta ocasión el prior había llegado a responderle airado, y a exclamar: «que se fuese con la gracia de Dios y con su plata de humo y joyas de trasgos, o otras palabras semejantes» ${ }^{10}$.

Poco tiempo después, fray Juan solicitó un permiso de quince días para salir del monasterio y acudir a la localidad de Ibdes, situada en la comarca de Calatayud, a 117 kilómetros al suroeste de Zaragoza, y famosa desde antiguo por sus aguas medicinales. Acababa de morir uno de sus hermanos y su familia le había pedido ayuda para solucionar ciertos asuntos económicos. Se trataba de intentar vender algunas tierras del fallecido, que vivía en la localidad cercana de Munébrega — de donde era oriundo fray Juan-, y de ese modo poder pagar las deudas que la familia debía a la comunidad de Calatayud. La ausencia del monasterio se justificaba también como una cura necesaria debido al pésimo estado de salud del fraile, ya anciano, quien, como tantos otros alquimistas, se encontraba aquejado del pecho debido al humo que había respirado a lo largo de su vida:

Por la falta de salud y ocupaçion grande del pecho que tenia [...] enbio a pedir licencia a su Padre General para que, yendo a proveher las neçesidades de la repartiçion y vendiçion de la hazienda sobredicha, pudiese convalesçer de la grande indisposicion que avia tenido, siendo regalado de su hermana y tomando los baños y otros remedios a proposito de su salud ${ }^{11}$.

El prior le concedió el permiso sin reparos, y el 31 de abril de 1593 fray Juan abandonó el monasterio, acompañado de un arriero, alcanzando su destino dos días después. Al llegar a Ibdes, se encontró con sus parientes más cercanos (sus hermanas: María, beata, y Jerónima, casada con Martín Lozano, con quien había tenido cuatro hijos), quienes, al parecer, lo recibieron con

\footnotetext{
Proceso contra fray Juan de Santa Ana, vol. I, fol. 264r.

Proceso contra fray Juan de Santa Ana, vol. I, fol. 264r.

1 Proceso contra fray Juan de Santa Ana, vol. II, fol. 21r.
} 
alivio y gran alborozo. Fray Juan había hecho transportar consigo los instrumentos necesarios para instalar su taller de alquimista en el mirador de la casa de su hermana Jerónima, donde se alojó durante casi dos semanas. Según el testimonio de algunos, buena parte de su estancia la pasó trabajando en dicho mirador hasta que, justo un día antes cumplirse el plazo para volver al monasterio, tanto él como su familia fueron mandados arrestar por los jurados de Calatayud, acusados de «monederos falsos $»{ }^{12}$.

\section{EL MONASTERIO COMO REFUGIO}

A partir de ahí, desconocemos el paradero de la familia del fraile. En cambio, poseemos un volumen extraordinario de información acerca de fray Juan. Por pertenecer a la orden de los jerónimos, se hallaba exento de jurisdicción, tanto ordinaria como eclesiástica. Pero, dada la importancia de la acusación, se hizo una excepción por orden del rey, el cual ordenó al nuncio papal en España que encargara al arzobispo de Zaragoza la instrucción de un proceso contra el fraile ${ }^{13}$. El extenso y detallado juicio, que se prolongó a lo largo de tres años, se ha conservado hasta hoy, encuadernado en dos gruesos tomos de tamaño folio, que suman un total de 1.570 páginas.

12 El 16 de mayo de 1593, los jurados de la comunidad de Calatayud dieron orden de apresar a fray Juan de Santa Ana y a su familia. A continuación, se iniciaron dos procesos criminales por parte de la justicia seglar: uno contra «Martin Lozano et aliorum» y otro contra el fraile. Ninguno de ellos se ha conservado. El 10 de julio del mismo año, el proceso de fray Juan fue traspasado a la justicia episcopal. Dentro del proceso incoado por el vicario del arzobispo de Zaragoza, se conserva la «demanda criminal del procurador fiscal de su magestad» que fue presentada contra el fraile en un primer momento.

13 Tras los 44 artículos de la acusación fiscal presentada por el «fiscal de su Magestad», Antonio Pérez Godino, contra fray Juan, se añadía la siguiente observación: «Siendo como es el dicho fray Joan de Santa Anna exempto de la ecclesiastica y ordinaria jurisdicçion por ser frayle proffesso de la orden y regla del señor Sant Geronimo, y para que tan graves delictos arriba recitados y por el cometidos no quedassen sin castigo, por orden y a instançia de la Magestad del Rey Nuestro Señor, el Illustrisimo y Reverendissimo Nuncio de su Santidad que reside en los Reynos de España cometio al dicho Illustrissimo Serñor Arçobispo de Çaragoça, y por el consiguiente a Vuestra Merced, dicho señor Vicario General, el conosçimiento, puniçion y castigo de los dichos crimines y delictos, mediante un breve y supplicacion en el introclusa, el qual se ha presentado a Vuestra Merced, dicho señor Vicario General, y por Vuestra Merced ha sido acceptado y, a supplicacion del dicho procurador fiscal, Vuestra Merced ha mandado prender la persona del dicho fray Joan de Santa Anna, y ha tenido y tiene presa en las carceles archiepiscopales de la presente ciudad [...]» (Proceso contra fray Juan, vol. I, fols. 34r-v). 
Tratándose de una causa criminal, las prolijas indagaciones que se llevaron a cabo durante todo este tiempo se encaminaron a averiguar si la acusación lanzada contra el monje era cierta para, de ser así, castigarlo como se merecía. En este caso, sin embargo, la determinación de la verdad o falsedad de la acusación iba a trascender más allá de la simple resolución de un pleito particular. No sólo se trataba de decidir si el reo había fabricado o no moneda adulterada: las intenciones del fraile, y de algún modo también la función, el significado y el alcance de la alquimia, iban a verse involucrados y puestos en entredicho.

Falsificar moneda se consideraba uno de los máximos atropellos contra la justicia, hasta el punto de equipararse a un delito de alta traición. Si bien es cierto que cualquier tipo de fraude era visto en sí mismo como una deslealtad, en el caso concreto de la falsificación de moneda se entendía que, más que nunca, estaba poniéndose en cuestión la autoridad sagrada del rey, a quien, como representante de Dios, correspondía el monopolio de su emisión. Al mismo tiempo, quienes falsificaban moneda, atentaban también contra la soberanía del Estado y contra la sociedad en su conjunto, ya que ello implicaba socavar la confianza pública en el comercio, una vez burlado el valor de su principal objeto de intercambio. Dicho crimen se consideraba, por consiguiente, de lesa majestad divina y humana, $\mathrm{y}$, dada su doble naturaleza, en tanto que pecado y delito debía ser juzgado por el fuero mixto (justicias espiritual y temporal) $)^{14}$.

La importancia concedida al derecho penal monetario fue en aumento en toda Europa desde finales de la Edad Media, sobre todo a partir de la formación de los llamados Estados modernos. Hay que tener en cuenta que, en comparación con hoy en día, todavía a finales del siglo XVI fabricar moneda falsa resultaba una tarea relativamente sencilla, pues la elaboración de moneda legítima seguía siendo bastante rudimentaria. La necesidad de compensar dicha facilidad práctica y el consiguiente miedo a la proliferación de falsarios explica la extrema gravedad teórica atribuida al delito. Buena muestra de ello es la recopilación de los Fueros de Aragón, en los que tanto el procedimiento inquisitivo como la aplicación de tormento quedaban absolutamente prohibidos a la hora de juzgar cualquier delito, excepto en los casos de crímenes

14 Véanse TomÁs y VAliente, F. (1992), El derecho penal de la monarquía absoluta (siglos XVI, XVII y XVIII), Madrid, Tecnos, p. 271; WürTTENBERG, Th. (1957), Un aspecto de la historia de falsificación de moneda, Anuario de Derecho Penal y Ciencias Penales, 10 (1), pp. 159-168, y LluIS Y NAVAS, J. (1963), La falsificación de moneda ante el Corpus Juris Canonici, Numisma, 62, pp. 19-44. 
excepcionalmente graves o «atroces» ${ }^{15}$. De manera significativa, entre estos se incluían el bandolerismo, la brujería y la falsificación de moneda; quienes los cometían eran considerados absolutamente nefastos y, por tanto, merecedores de ser castigados con la pena de muerte de la forma más rápida y eficaz posible. En el caso de que tales crímenes fueran consumados por miembros del clero, el procedimiento habitual consistía en aplicar primero la pena de degradación, en virtud de la cual el reo quedaba privado de todas las prerrogativas que, como clérigo, le correspondían ${ }^{16}$.

Dada la seriedad del delito del que se acusaba a fray Juan, pese al privilegio de exención jurisdiccional que disfrutaban los monjes de su orden ${ }^{17}$, se consideró necesario que su caso fuera instruido competentemente. Desde el principio se contó con la completa aquiescencia de los poderes temporal y espiritual, esto es, tanto del rey Felipe II como del nuncio apostólico en España: Camilo Gaetano, patriarca de Alejandría, en representación de su santidad el papa Clemente II. La solemnidad del procedimiento y la gravedad atribuida al asunto no impidieron que - afortunadamente para el reo- su caso fuera investigado con admirable imparcialidad y benevolencia, y asimismo que - afortunadamente para nosotros-, tanto los interrogatorios a testigos como el resto de averiguaciones se llevaran a cabo con un detalle y un cuidado exquisitos.

Antes de abordar las principales líneas de argumentación que forman la urdimbre del caso - tan contradictorias entre sí que a menudo nos invitan a contemplarlo desde puntos de vista enigmáticamente opuestos-, conviene señalar las coordenadas espacio-temporales en que se enmarca. Dos aparentes casualidades resultan particularmente elocuentes. Por un lado, el proceso se inició en 1593, fecha que coincide con el año de publicación del tratadito ya mencionado dedicado a Felipe II, destinado a distinguir a los alquimistas fraudulentos de los auténticos. Por otro lado, la mayor parte de las operaciones alquímicas del reo tuvieron lugar en el ámbito de un monasterio de la orden jerónima que, al igual

15 Véase Savall y Dronda, P. y Penén y Debesa, S. (1886), Fueros, observancias y actos de corte del reino de Aragón, Zaragoza, Francisco Castro y Bosque, 1866 (existe una ed. facsímil publicada en 1991 en Zaragoza por Ibercaja).

16 Véase Lluis Y NAVAS-BruSI, J. (1956), La falsificación de moneda ante los Fueros y Observancias de Aragón, Numisma, 22, pp. 63-86.

17 En 1414, los monjes de la orden jerónima obtuvieron del papa Benedicto XIII la bula «Licte Exigente», por la cual quedaban exentos de la jurisdicción episcopal. Véanse RUIZ HeRnando, J.A. (1997), Los monasterios jerónimos españoles, Segovia, Caja de Segovia; y CAmpos, J. y Fernández de Sevilla, F. (coords.) (1999), La Orden de San Jerónimo y sus Monasterios, San Lorenzo de El Escorial, EDES. 
que el monasterio —entonces también jerónimo - de El Escorial, constituía un importante polo de atracción para muchos alquimistas ${ }^{18}$.

No hay que olvidar que, a pesar del auge de las universidades, en la España de finales del siglo XVI los monasterios todavía seguían desempeñando un papel decisivo como centros no sólo de religiosidad, sino de cultura en un sentido más amplio. San Lorenzo de El Escorial constituía un caso especial, por ser el lugar elegido por Felipe II como residencia, lo que automáticamente lo hacía ser considerado un lugar sagrado por excelencia. A ello se unía la numerosa colección de reliquias que el rey se afanaba personalmente por aumentar y que contribuían a santificar el lugar ${ }^{19}$.

En este sentido, el monasterio zaragozano de Santa Engracia no le iba a la zaga pues, según la leyenda de los Innumerables Mártires, albergaba más reliquias que ningún otro lugar (en particular, las conocidas como «Santas Masas») por haber sido la Zaragoza de los primeros tiempos del cristianismo objeto de una de las más feroces persecuciones llevadas a cabo por el emperador Diocleciano ${ }^{20}$. Tanto el monasterio de San Lorenzo de El Escorial como el de Santa Engracia de Zaragoza hacían honor a dos famosos mártires de la época apostólica. Algunos estudiosos, a la vista de la constante reactualización de los sufrimientos de los primitivos mártires y del intenso culto a las reliquias que se observa en la Edad Moderna, en especial desde finales del

18 Véanse CAmpos, J. y Fernández de Sevilla, F. (coords.) (1994), La ciencia en el Monasterio del Escorial, San Lorenzo del Escorial, EDES; RODRÍGUEZ GUERRERO, J. y RoJAS GarcíA, P. (2001), La Chymica de Richard Stanihurst en la Corte de Felipe II, Azogue, 4, disponible en http://www.revistaazogue.com (consultado el 25 de agosto de 2011), y REY Bueno, M. (2009), La Mayson pour Distiller des Eaües at El Escorial: Alchemy and Medicine at the Court of Philip II, 1556-1598. En Huguet-Termes, T., Arrizabalaga, J. y CoOK, H. (coords.), Health and Medicine in Hapsburg Spain: Agents, Practices, Representations, Londres, Wellcome Trust Centre for the History of Medicine at UCL, pp. 26-39.

19 «Había el prudentísimo monarca alcanzado licencia, privilegios y breves de los Sumos Pontífices para sacar por las más lícitas y santas maneras que pudiese, de toda Alemania, reliquias de todos los santos de cualquier iglesia o monasterio que quisiesen condescender a sus peticiones, y de cualquier tamaño o grandeza, aunque fuesen cuerpos enteros de santos [...] porque muchas de ellas no eran veneradas en los lugares que estaban con la decencia que era razón, y por el peligro que corrían en venir a manos de los herejes, que como tan del bando del enemigo de Dios, hacen guerra sangrienta a sus santos», en SIGÜENZA, J. (1988), La fundación del Monasterio del Escorial, Madrid, Aguilar, pp. 236-238.

20 Véase TAUSIET, M. (2008), Zaragoza celeste y subterránea: geografía mítica de una ciudad (ss. XV-XVIII). En DELPECH, F. (ed.), L'imaginaire du territoire: représentations fabuleuses des lieux et de l'espace péninsulaires en Espagne et au Portugal (XVI ${ }^{e}-X V I I^{e}$ siècles), Madrid, Casa de Velázquez, pp. 141-170. 
siglo XVI y durante la primera mitad del XVII, han calificado este período de «edad de oro de la martirología» ${ }^{21}$.

En efecto, gran parte de la fama del monasterio de Santa Engracia se debía a los constantes milagros atribuidos a los mártires enterrados en su subsuelo. Los prodigios que continuamente desplegaban, ya abundantes de por sí, aumentaban sensiblemente cada vez que alguien solicitaba alguna reliquia para llevársela consigo, como si tales milagros representaran señales certeras de la resistencia de los espíritus redivivos a que sus restos mortales fueran trasladados a otro lugar ${ }^{22}$. En su visita a Zaragoza en 1586, Felipe II, impresionado ante el relato de los portentos y calamidades que se habían producido en el pasado cada vez que se había intentado exhumar algún hueso, a pesar de haber pedido en un primer momento al monasterio «con grandes instancias» reliquias para su colección de El Escorial, finalmente «mando que ningun sepulcro se abriesse ${ }^{23}$. Pero, al margen del aura de sacralidad de los dos principales relicarios de la España moderna, ambos monasterios compartían otras muchas características, dada su pertenencia a la orden jerónima, y además se hallaban estrechamente relacionados entre sí.

Uno de los más declarados admiradores del monasterio de Santa Engracia fue el historiador, teólogo y humanista fray José de Sigüenza, monje también jerónimo que a partir de 1590 estableció su residencia definitiva en El Escorial, a petición de Felipe II, desempeñando un importante papel en la organización de la biblioteca del monasterio junto a Benito Arias Montano. Envidiado por gozar de la predilección del rey e incomprendido ante su ardiente defensa de los evangelios, en 1592 sufrió un proceso inquisitorial como sospechoso de herejía, del que salió absuelto al año siguiente, probablemente gracias al apoyo real. En 1598, nada más fallecer Felipe II, Sigüenza fue elegido prior del zaragozano monasterio de Santa Engracia, aunque nunca llegó a tomar posesión del cargo por ser a su vez reclamado por Felipe III, quien

21 Véase Johnson, T. (1996), Holy Fabrications: The Catacomb Saints and the CounterReformation in Bavaria, Journal of Ecclesiastical History, 47 (2), pp. 274-297, p. 280, y DitchFIELD, S. (1993), Martyrs on the move: relics as vindicators of local diversity in the Tridentine Church. En WooD, D. (ed.), Martyrs and Martyrologies, Studies in Church History, XXX, pp. 283-294.

22 Tales prodigios aparecen constatados en la obra del jerónimo MARTóN, L.B. (1737), Origen y antiguedades de el subterraneo y celeberrimo santuario de Santa Maria de las Santas Masas, oy Real Monasterio de Santa Engracia de Zaragoza, Zaragoza, Juan Malo, pp. 550-578.

23 MARTÓN (1737), p. 560. 
alegó «que lo necessitava para el Escorial» ${ }^{24}$. El puesto terminó siendo ocupado por el padre Juan Vaguer, «prelado de célebre memoria», que ya había sido prior de Santa Engracia entre 1591 y 1595. Como ya se ha apuntado anteriormente, dicho período coincidió con la estancia de fray Juan de Santa Ana, a quien en cierta ocasión Vaguer había reprendido irritado, tras haberle rogado repetidas veces que renunciara a su oficio de alquimista.

DESCRIPCION, Ò MAPA, DEL REAL MONASTERIO, y Parroquia de Santa Engracia de Zaragoza.

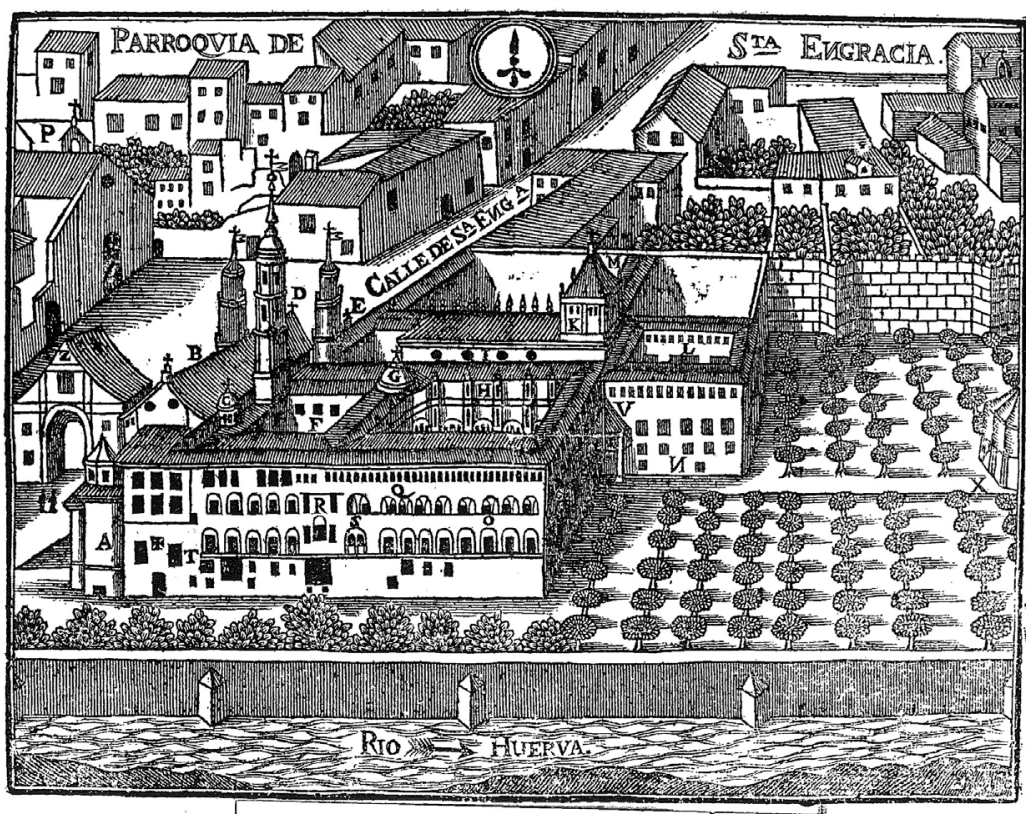

Monasterio de Santa Engracia de Zaragoza (León Benito Martón, Origen y antiguedades de el subterraneo y celeberrimo santuario de Santa Maria de las Santas Masas, oy Real Monasterio de Santa Engracia de Zaragoza, Zaragoza, 1737, pp. 10-11).

El padre Sigüenza nunca llegó a formar parte de la comunidad monástica de Santa Engracia, pero sin duda conocía muy bien el lugar. Su Historia de la

24 MARTÓN (1737), p. 576. 
orden de San Jerónimo, escrita entre 1600 y 1605, incluía una descripción detallada del convento: «un santuario tan grande y de tanta devoción que se atreve san Prudencio a decir que apenas le hace a Roma ventaja». Según Sigüenza, aparte de por su gran tamaño, el convento destacaba por su privilegiada situación, «puesto a Mediodía» y a la orilla de «un río muy grande, que se llama Huerva ${ }^{25}$. En realidad, se trataba de una zona periurbana, situada en el exterior de la muralla romana, que servía de contacto entre el campo y la ciudad y que, ya desde antiguo, se había considerado territorio sagrado por ser un área cementerial, regada por la sangre de los «innumerables mártires» de la ciudad ${ }^{26}$.

En 1493, Fernando el Católico decidió fundar allí un monasterio para cumplir el deseo incumplido de su padre Juan II de Aragón: agradecer a la virgen y mártir Santa Engracia con su construcción la recuperación de la vista tras sufrir una operación de cataratas. Aun así, la finalización del edificio, en estilo plenamente renacentista, no tuvo lugar hasta 1540. A partir de entonces son abundantes los testimonios procedentes de viajeros y peregrinos acerca de su suntuosidad y belleza ${ }^{27}$. Gracias a las generosas dádivas de los dos últimos monarcas de la corona de Aragón y al apoyo continuado de los primeros reyes de la casa de Austria, el conjunto monástico llamaba la atención por su amplitud y riqueza. Además del templo, y de la famosa cripta subterránea donde aún se custodian las reliquias de los Innumerables, el edificio albergaba tres grandes claustros, refectorio, hospedería, biblioteca, enfermería, botica, bodega, capilla, e incluso una granja. Todo ello sin contar, por supuesto, con las celdas individuales características de los monasterios jerónimos, donde dormían y oraban los monjes en soledad, como reminiscencia de los orígenes eremíticos de la orden ${ }^{28}$. Entre las dependencias del monasterio, Sigüenza destacaba una alta y hermosa torre, desde cuya azotea podía divisarse «una

25 SigüenZA, J. (2000), Historia de la orden de San Jerónimo, Valladolid, Junta de Castilla y León, p. 62.

26 Véanse Buesa Conde, D. (1992-1993), Consideraciones urbanísticas en torno al Santuario de Santa Engracia. De la calle de Santa Engracia al Paseo de la Independencia, Aragonia Sacra, VII-VIII, pp. 349-390; GARCÍA TERREL, A.M. (1999), El barrio y la parroquia de Santa Engracia de Zaragoza entre 1600 y 1900, Zaragoza, Gobierno de Aragón; y Ansón, A., Cabanes, M. de los D., Conde, E., Ibáñez, J., Lacarra, C., Laguens, M., Minguell, J.A., Morte, C. y Mostalac, A. (2002), Santa Engracia. Nuevas aportaciones para la historia del monasterio y basílica, Zaragoza, Gobierno de Aragón, Ayuntamiento de Zaragoza y Parroquia de Santa Engracia.

27 Véase Domínguez Lasierra, J. (1992-1993), El Monasterio de Santa Engracia de Zaragoza: el asombro de los viajeros, Aragonia Sacra, pp. 161-172.

28 Véase RuIZ HERNANDO (1997), pp. 35 y ss. 


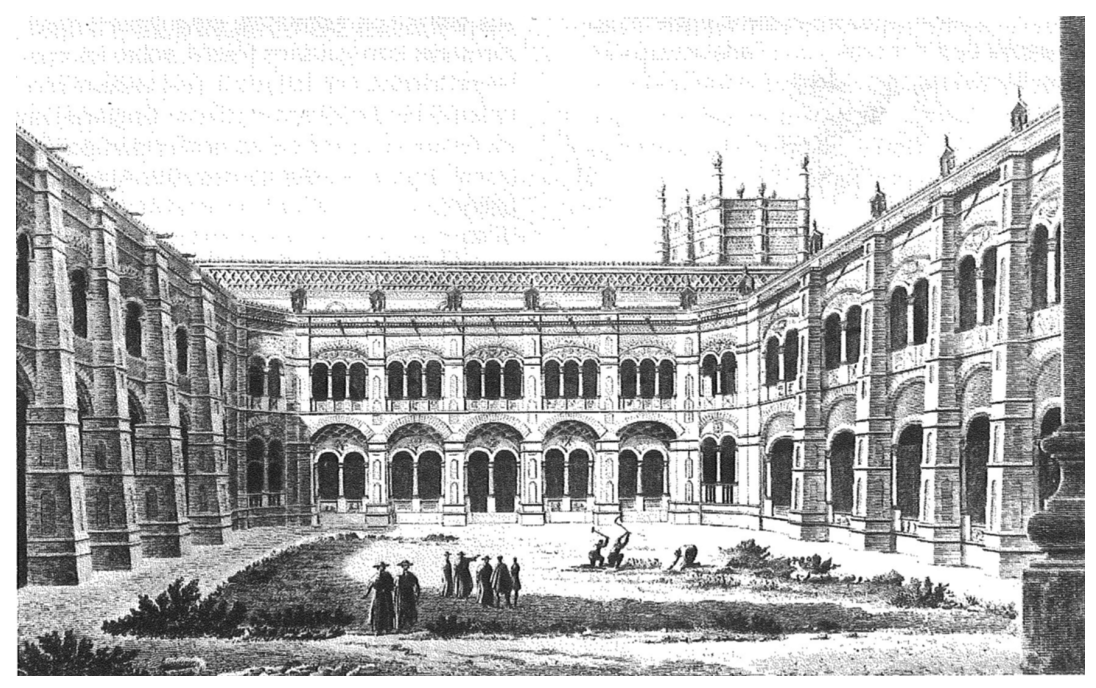

Vista interior del monasterio de Santa Engracia de Zaragoza (Louis François Lejeune, 1806).

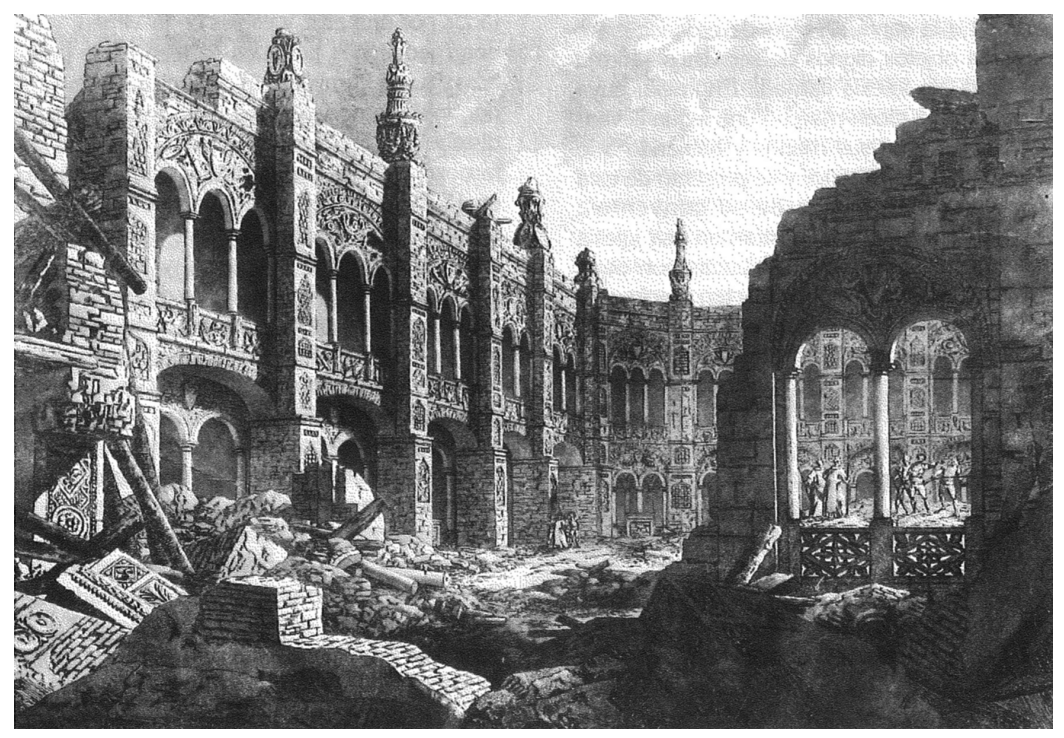

Ruinas del monasterio de Santa Engracia de Zaragoza, destruido durante la Guerra de la Independencia (Fernando Brambila y Juan Gálvez, 18081812). 
larga y apacible vista» que englobaba la ciudad entera y, asimismo, «los ríos que la ciñen en contorno, una vega de cuatro leguas en largo y muchos lugares y casas de campo, las sierras del Moncayo y aun los Pirineos» ${ }^{29}$.

Este era el lugar, en principio ideal, en que fray Juan de Santa Ana iba a trabajar con denuedo y entusiasmo durante dos años en su particular búsqueda de la piedra filosofal. Por los datos contenidos en el proceso incoado por el arzobispo de Zaragoza, sabemos que el anciano monje había llegado al monasterio de Santa Engracia en 1591, procedente de San Bartolomé de Lupiana (Guadalajara), donde era profeso. No conocemos el motivo del traslado, pero sí el trato deferente y respetuoso de que iba a ser objeto en su nueva residencia, incluso a pesar de las crecientes sospechas que sus actividades iban a suscitar. Según el testimonio de fray Domingo Murillo, de treinta y cuatro años de edad, en cierta ocasión «un ministro de la moneda de su Magestad» llamado Hernando Truxaron había visitado el monasterio para contrastar ciertas habladurías, ya que:

habia entendido que el dicho fray Juan y ciertas personas desta ciudad hazian del estaño plata. Y que era grandissima maldad, que aquello no lo podia hazer sino su Magestad o sus ministros. Y que si no lo remediaban, que a los seglares les haria dar cien azotes y inbiarlos a galeras, y que al frayle le haria tambien castigar por la orden ${ }^{30}$.

Vista la situación, en vez de echar leña al fuego, fray Domingo «lo procuro de aplacar, pareciendole que tenia mucha colera» y asimismo "se encargo de hablar sobre ello al dicho fray Juan de Santa Ana para que dexase las dichas invenciones ${ }^{31}$. No obstante, finalmente no se atrevió a hacerlo:

no se lo oso dezir [...] porque por ser el dicho fray Juan del monasterio de Sant Bartholome de Lupiana, que es mayor de dicha orden, y por ser guesped, parece que habia obligacion de no darle pesadumbre ${ }^{32}$.

A lo que parece, esta actitud reservada era compartida por la mayoría de los monjes, ya fuera por prudencia o simplemente por miedo. Fray Domingo había oído decir a algunos frailes del monasterio que sospechaban que fray Juan pudiera estar fabricando moneda falsa, pero que, aun siendo un «grave negocio»",

29 SigüEnZA (2000), p. 65.

30 Proceso contra fray Juan de Santa Ana, fol. 257v.

31 Proceso contra fray Juan de Santa Ana, fol. 258r.

32 Proceso contra fray Juan de Santa Ana, fol. 258r. 
no lo habian osado comunicar con nadie por no caer en las penas que tiene puestas su religion, que el que dixere algo de otro y no probare ser verdad conforme a derecho, le hazen pasar por la propia pena ${ }^{33}$.

El entorno que rodeaba a fray Juan en el monasterio ya no podía ser más favorable. No sólo disponía de un lugar apacible y cómodo donde lograr el aislamiento y la concentración necesarios, sino que, además, se encontraba a salvo de cualquier acusación malintencionada. La sacralidad del espacio conventual representaba para él un refugio, un auténtico asilo frente a la posible acción de la justicia. Sin embargo, no todo era miel sobre hojuelas. A pesar de la fama de la riqueza y esplendor del monasterio, sabemos que, precisamente entre 1591 y 1593 , coincidiendo con el traslado de fray Juan y el primer priorato del padre Vaguer, el convento atravesó por una situación de crisis económica especialmente delicada.

Tal y como resaltaría posteriormente el padre Martón en su detallada crónica de la historia del monasterio, fray Juan Vaguer, nada más aceptar su cargo como prior, «hallo a la comunidad empeñadisima y llena de deudas» ${ }^{34}$. Ello le llevó a pedir socorro del rey Felipe II en 1592, alegando que, tal y como había dispuesto su abuelo Fernando el Católico, el número de monjes que vivía en el convento era cincuenta. Ahora bien, dada la carencia de medios para su manutención, si nada lo remediaba, se verían obligados al «estrecho insufrible de quitar la mitad, cessando mucho Culto de los Santos Martyres, ò al de aver de vivir empeñadissimos, lo que con el tiempo avia de anhiquilarlo todo» ${ }^{35}$.

La respuesta a la apurada solicitud iba a tardar en producirse casi dos años. En 1594 llegó un desalentador comunicado del monarca diciendo que «no huviesse mas religiosos de los que pudieren sustentarse con la renta actual», a lo que Vaguer volvió a insistir en que «sin el numero de cinquenta no podia subsistir el devido coro de dia y de noche de estas cryptas». Finalmente, Felipe II, en un despacho emitido desde El Escorial a 9 de julio de 1594, concedió licencia al monasterio para sacar, de Valencia, «setenta y cinco mil ducados de mercaderias a Argel y Berberia en tres años ${ }^{36}$. Resulta, por tanto, indudable que el período en que fray Juan se trasladó a Santa Engracia coincidió con un momento particularmente crítico, del que se derivaron repercusiones no sólo económicas sino también psicológicas para sus residentes. En la crónica

\footnotetext{
33 Proceso contra fray Juan de Santa Ana, fol. 256r.

34 MARTÓN (1737), p. 573.

35 MARTÓN (1737), p. 573.

36 MARTÓN (1737), p. 573.
} 
del monasterio ya mencionada, Martón llega incluso a referirse a la «angustia» y las «turbaciones» que precedieron la llegada de ayuda monetaria ${ }^{37}$.

Si la crisis económica generalizada ${ }^{38}$ afectó de tal manera a un centro monástico sustentado en gran medida por rentas reales, capellanías y limosnas, el impacto que se observa en muchas áreas rurales fue incomparablemente más grave. Como veremos más adelante, la situación de carestía en que se encontraba la familia del monje iba a desempeñar un papel decisivo en el curso de los acontecimientos. La mayoría de los conflictos y altercados característicos de esta época tenían mucho que ver con las difíciles condiciones de vida padecidas por sus protagonistas, y tras el imponente proceso contra el fraile se escondía una riña entre vecinos con sus consiguientes secuelas de venganza. Según afirmación de uno de los testigos que declararon en el proceso contra fray Juan, sus familiares más cercanos vivían en un extremo de pobreza que rayaba en la inanición:

Que los dichos Martín Lozano y Gerónima Rubio y sus hijos estaban y vivian con mucha necesidad y pobreza antes de que viniesse a su casa el dicho fray Juan de Santa Ana, y que no tenian aun con que comprar una media de trigo, hasta que el dicho fray Juan de Santa Ana vino al dicho lugar de Ibdes [...], que entonces compraron un cahiz de trigo. Y este testigo le oyo dezir a la mujer de Miguel Ybañez, llamada la Romera, que ella les habia prestado dos o tres arnerillos de arina dos dias antes que viniese el dicho fray Juan de Santa Ana, y que se perecian de hambre ${ }^{39}$.

Obviamente, el fiscal del rey en el reino de Aragón, al redactar la demanda criminal contra fray Juan, iba a aprovechar esta información para ponerla en estrecha relación con el grave crimen atribuido al reo. Según constaba en la acusación criminal, la familia del fraile vivía en la penuria, entre otras razones «por haverse jugado y menoscabado la hazienda» el marido de su hermana. De ahí que fray Juan llevara varios años dedicado «a hazer plata falsa [...] aunque en lo publico decia que trataba de hazer imagines y cossas de devo-

37 MARTón (1737), p. 573. No olvidemos que a partir de mayo de 1591 se produjeron importantes motines y tumultos en Zaragoza con motivo del encarcelamiento de Antonio Pérez por la Inquisición, lo que se consideró una intromisión y una falta de respeto a los fueros de Aragón. Véase GASCón PÉREZ, J. (1995), Bibliografía crítica para el estudio de la rebelión aragonesa de 1591, Zaragoza, Centro de Documentación Bibliográfica Aragonesa.

38 Sobre la situación de la economía española a finales del siglo XVI y a lo largo de la centuria siguiente, véanse: PARKER, G. (1997), The general crisis of the seventeenth century, New York, Routledge; y Gallardo, A. (2002), Spanish Economics in the 16th Century: Theory, Policy, and Practice, Lincoln, Writers Club Press.

39 Proceso contra fray Juan de Santa Ana, vol. I, fol. 112r. 
cion». Dada la «muy grande y extrema necessidad» en que se encontraban sus parientes, lo que fray Juan perseguía era «hazer que fuessen muy ricos». Mientras tanto, los consolaba y animaba diciéndoles «que se esforçassen y no pasassen pena, que el con su industria los sacaria de necessidad y haria que estuviessen muy ricos y sobrados» ${ }^{40}$.

\section{EQUÍVOCA QUINTAESENCIA}

Entre la ilusión de alcanzar un estado de sobrada riqueza y la extrema miseria justificativa del crimen, no obstante, existía un punto intermedio. Del mismo modo, entre la interpretación materialista de las actividades del reo presentada por el fiscal, y el ideal alquímico-espiritual defendido por el monje, se abría un ancho horizonte de incertidumbre y ambigüedad. Sea o no cierto que fray Juan llegara a acuñar - $\mathrm{O}$ a intentar obtener - moneda suficiente para remediar la necesidad de sus deudos, si algo resulta patente tras la lectura de los cientos de páginas dedicadas a investigar su caso es que, de serlo, éste no constituía su único objetivo. Según el fraile, su intención a corto plazo se reducía a esculpir imágenes sagradas en plata, pero su auténtica meta era descubrir el secreto de la quintaesencia o piedra filosofal. En relación con lo primero, tal y como consta en el resumen de su primer interrogatorio ante la justicia episcopal, el reo

\footnotetext{
tenia muchos instrumentos, receptas y advertencias para hazer plata de metales baxos como son cobre o argenvino [...] y aun pretendia [...] que se podia hazer una cruz grande muy buena con harto poco coste, con muchos caliçes. Y para este effecto tenia muchos papeles y cartapaçicos, porque [...] era curioso en trasladar todos los papeles que podia saber desta materia, para escoger lo que fuese bueno, y no para hazer cosa contra leyes del reino ni contra conciencia ${ }^{41}$.
}

En cuanto al método para alcanzar su objetivo final - esto es, la purificación completa de la materia mediante la ansiada piedra—, según fray Juan, consistía en ir depurando un metal tras otro, aplicando a cada uno las medicinas dirigidas a lograr su progresivo perfeccionamiento. Por ello, no desdeñaba ninguna receta antes de probarla por sí mismo. De acuerdo con el resumen de su segundo interrogatorio:

40 Proceso contra fray Juan de Santa Ana, vol. I, fols. 24 y 25 r.
41 Proceso contra fray Juan de Santa Ana, vol. I, fol. 40v. 
Todas las receptas que a sus manos han venido las ha recogido, y lo que trata de purificar es el cobre o arambre o argento vibo en receptas que se juntan con mezcla y ayuda de plata; no lo haze para hazer plata falsa, sino para saber la purificacion de los tales metales y hazer la projection de la piedra mineral en la purificacion que destas purificaciones pareciera mejor ${ }^{42}$.

La filosofía en que fray Juan basaba sus experimentos era la misma que había guiado a muchos otros alquimistas anteriores a él desde los tiempos más remotos: la idea básica según la cual cada elemento del mundo creado tiende siempre a la perfección ${ }^{43}$. Teniendo en cuenta que el ritmo de la naturaleza es extremadamente lento, el ideal perseguido por la alquimia consistiría precisamente en acortar lo más posible el tiempo natural que a cada elemento le era necesario para alcanzar su nivel de excelencia ${ }^{44}$. Para ello había que buscar un agente capaz de acelerar los procesos espontáneos, una especie de medicina o remedio aplicado a la materia que consiguiera refinarla cuanto antes, lo que implicaba su conversión en oro o plata puros, en un doble sentido material y simbólico. Dicha medicina o agente se identificaba con la mítica piedra filosofal, conocida también como quintaesencia, elixir vital, panacea universal, etc.

En una lectura espiritual, se suponía que su hallazgo se hallaba reservado a unos pocos sabios, que al mismo tiempo que se afanaban en el perfeccionamiento del mundo exterior debían depurarse también a sí mismos, coincidiendo de este modo la catarsis de la materia con la purificación interior de los practicantes del arte ${ }^{45}$. Tal aspiración no figuraba, sin embargo, entre las afirmaciones y los escritos del monje, lo que confirma el escepticismo de algunos estudiosos actuales acerca de las lecturas psicológicas de la alquimia que no han dejado de estar en boga desde comienzos del siglo pasado hasta

42 Proceso contra fray Juan de Santa Ana, vol. I, fol. 62r.

43 Véanse KOYRÉ, A. (1955), Mystiques, spirituels, alquimistes du XVI siècle allemand (Schwenckfeld, Franck, Weigel, Paracelse), París, Armand Colin (trad. esp., Misticos, espirituales y alquimistas del siglo XVI alemán, Madrid, Akal, 1981), y MORAN, B.T. (2005), Distilling Knowledge. Alchemy, Chemistry, and the Scientific Revolution, Cambridge (Massachusetts), Harvard University Press.

44 Michael Maier sostenía en 1617 que «el tiempo de la naturaleza es extremadamente largo, su forma de hacer la cocción es uniforme y su fuego es muy lento; el del arte, por el contrario, es corto, el calentamiento se controla por la inteligencia del artista, y el fuego también se hace más intenso o más debil» (citado en READ [1957], p. 34).

45 Véanse JunG, C.G. (1944), Psychology and Alchemy. Introduction to the religious and psychological problems of alchemy. En Collected Works of Carl Gustav Jung, vol. 12, Princeton, Princeton University Press, pp. 1-37 (trad. esp., Psicología y alquimia, Barcelona, Plaza y Janés, 1989), y EliADE, M. (1956), Forgerons et alchimistes, Paris, Flammarion (trad. esp., Herreros y alquimistas, Madrid, Alianza Editorial, 1990). 


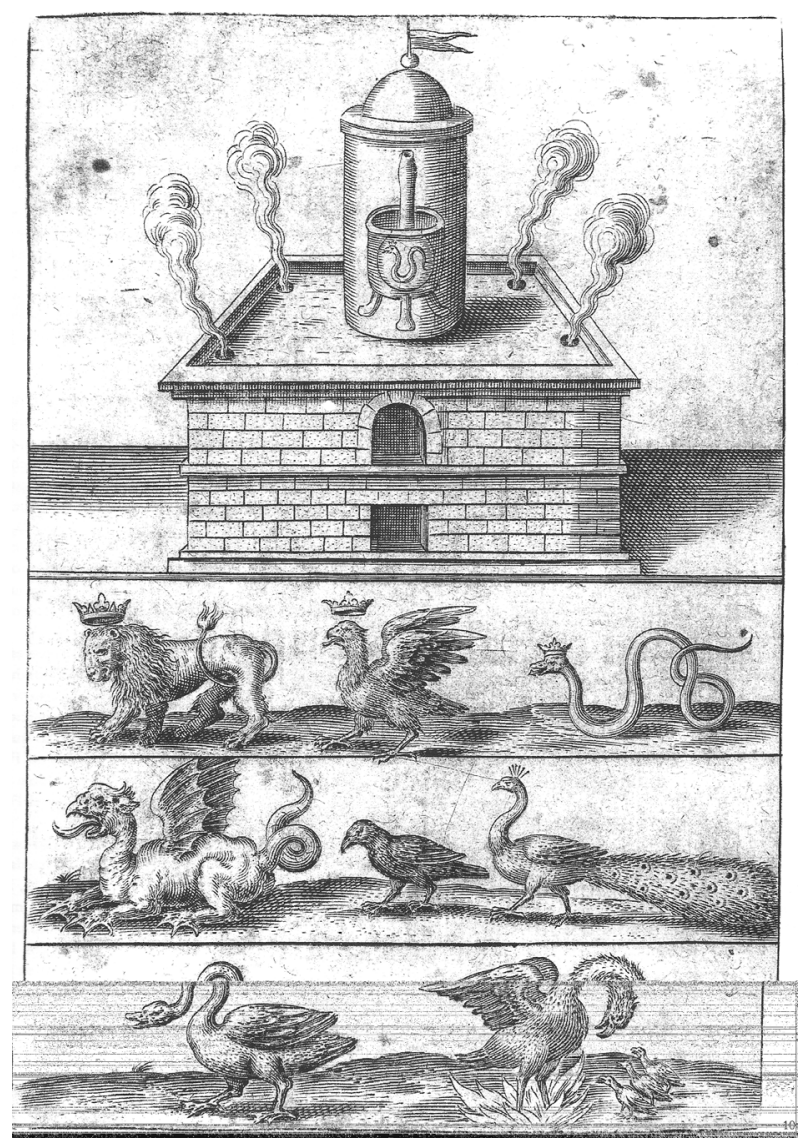

Atanor u horno alquímico. En su interior está el vaso con la serpiente, símbolo del Mercurio de los Filósofos. Abajo aparece el bestiario hermético (león, águila, serpiente, dragón, cuervo, pavo real, cisne y fénix). En Michael Maier, Tripus aureus, 1618, Fráncfort, 1618.

nuestros días. En realidad, dichas lecturas no representan sino interpretaciones románticas alejadas de la realidad cotidiana, y no por casualidad han sido elaboradas al margen de la investigación histórica, es decir, de la observación directa de casos concretos ${ }^{46}$.

46 La lectura espiritual de los experimentos alquímicos, tanto por parte de Jung como de Eliade (que todavía hoy en día sigue gozando de enorme popularidad, así como de aceptación, 
Sea como sea, a la vista de la erudición de fray Juan, así como de su pericia en el arte espagírico, el vicario del arzobispo en un segundo interrogatorio le preguntó de dónde había sacado tanta información como para haber sido capaz, él mismo, de redactar varios cuadernos llenos de fórmulas y procedimientos alquímicos. El reo respondió que la mayor parte de los libros que le habían servido de inspiración para componer sus propias recetas se encontraban en la biblioteca del monasterio de Santa Engracia (que, según el padre Sigüenza, contaba con más de dos mil volúmenes ${ }^{47}$. Entre tales libros, fray Juan destacó las obras de Aristóteles, Alberto Magno y Santo Tomás de Aquino, pero sobre todo un ejemplar que le había prestado el mismo prior, «cuyo autor se llama Cuadramo, medico, del qual ha sacado la mayor parte de las receptas y documentos contenidos en sus libros» ${ }^{48}$. Sin duda, demostrar que el sensato y bondadoso padre Juan Vaguer se hallaba implicado, aunque fuera mínimamente, en las ocupaciones del monje constituía para éste una plataforma inmejorable para la defensa de su causa ${ }^{49}$.

No hay que olvidar que, pese a las sospechas que las actividades de los alquimistas desataban por doquier, los principios en los que se basaba la utopía de alcanzar la piedra filosofal se hallaban íntimamente relacionados con las ideas de un buen número de eruditos y místicos cristianos, en cuyas obras los adeptos de la alquimia pretendían fundamentar la legitimidad de su arte. Sin embargo, la confusión era general, ya que la mayoría de las obras que circulaban acerca de la alquimia se atribuían a autores consagrados que nada tenían que ver con ellas, sin que ninguna voz se alzara para cuestionar dicho esta-

en muchos ámbitos académicos) se enmarca en el contexto de la atracción victoriana por un oculltismo idealizado que tendía a contemplar la alquimia desde un punto de vista esencialista, como si fuera algo constante e invariable a lo largo de la historia. Véase PRINCIPE, L.M. y Newman, W.R. (2001), Some Problems with the Historiography of Alchemy. En Newman W.R. y GRAFTON, A., pp. 385-431.

47 Según fray José de Sigüenza, la biblioteca del monasterio, muy amplia («de largo, ciento cincuenta y seis pies, y de ancho cuarenta y dos») y bien iluminada, albergaba «más de dos mil cuerpos de libros bien aderezados y de todas disciplinas» (SIGÜENZA [2000], p. 64).

48 Proceso contra fray Juan, vol. I, fol. 70v. El libro citado, de «un philosopho que se llama el doctor Cuadramo» se titulaba, según fray Juan, «De secretis naturae, maxime de mineralibus» (véase Proceso, vol. I, fol. 105r). Con toda probabilidad, se trataba de una versión más del libro De mineralibus escrito por Alberto Magno, de las muchas que, con dicho título u otro semejante, circulaban de mano en mano, dentro de lo que se ha dado en llamar la tradición del pseudo-Albertus. Véase EAMON (1994), pp. 71-73.

49 Según León Benito Martón, Juan Vaguer poseía una «rara humildad» unida a una sabiduría excepcional, que incluía el espíritu de profecía, sabiendo enlazar siempre «las letras con lo virtuoso» (véase MARTÓN [1737], p. 572). 
do de cosas. Resulta significativo a este respecto que una figura como Alberto Magno (probablemente el sabio universal más destacado de la Baja Edad Media por haber recuperado la filosofía de Aristóteles e introducido las obras científicas griegas y árabes en el ámbito escolástico) se considerara una de las máximas autoridades en la historia de la alquimia, pese a no haber escrito ninguna obra alquímica propiamente dicha. Su obra más cercana al arte era un libro sobre los minerales (De mineralibus), donde trataba de la constitución de éstos, así como de la posibilidad de su transmutación, que al final sólo juzgaba aparente o superficial. Aun así, Alberto constataba que, de todas las artes, la alquimia era la que mejor imitaba a la naturaleza, consiguiendo en ocasiones incluso perfeccionarla, lo que, en su opinión, le otorgaba un lugar preeminente en la filosofía natural ${ }^{50}$.

De manera similar, a Tomás de Aquino (el teólogo más destacado de su época, canonizado en 1323 y declarado doctor de la Iglesia en 1567) se le atribuía la autoría de varios textos alquímicos. Pero, aunque el doctor angélico consideraba la alquimia un subapartado de la filosofía natural, lo cierto es que también rechazó explícitamente la idea de la transmutación de la materia. Por contraste, en los tratados apócrifos publicados bajo su nombre, se insistía en que el fin de todos los metales era terminar siendo convertidos en oro y en plata, siempre que dispusieran del tiempo necesario en la mina para que la acción de la naturaleza pudiera manifestarse ${ }^{51}$. De acuerdo con este tipo de tratados que, en España, también se atribuyeron erróneamente tanto al beato Ramón Llull ${ }^{52}$ como al médico y teólogo Arnaldo de Villanova ${ }^{53}$, la transmutación de los metales podía efectuarse artificialmente ya que, tal y como defendía Aristóteles, lo que existe en potencia puede convertirse en acto. En consecuencia, todo cuerpo compuesto, animal o vegetal, podía ser reducido a mineral, y finalmente a oro o a plata, no solamente por la acción de la naturaleza, sino tam-

50 Véase Halleux, R. (1982), Albert le Grand et l'alchimie, Revue des sciencies philosophiques et théologiques, 66, pp. 57-80.

51 Véanse Halleux, R. (1979), Les textes alchimiques, Turnhout, Brepols Publishers, y Newman, W.R. (1989), Technology and Alchemical debate in the Late Middle Ages, Isis, 80, pp. 423-455.

52 Véanse PereIRA, M. (1989), The alchemical corpus attributed to Raymund Lull, Londres, Warburg Institute, y PEREIRA, M. (1992), L'oro dei filosofi. Saggio sulle idee di un alchimista del Trecento, Spoleto, Centro italiano di studi sull'Alto Medioevo.

53 Véanse GiRALt, S. (2003-2004), El mite d'Arnau de Vilanova, de l'Edad Mitjana al Renaixement, Estudi General, 23-24, pp. 127-142; GIRALT, S. (2005), Un alquimista medieval per als temps moderns: les edicions del corpus alquímic atribuït a Arnau de Vilanova en llur context (ca. 1477-1754). En PERARnAu, J. (ed.), Actes de la II Trobada Internacional d'Estudis sobre Arnau de Vilanova, Barcelona, Institut d'Estudis Catalans, pp. 61-128. 
bién mediante la intervención del hombre o, dicho de otro modo, mediante el «arte», en este caso, el arte de la alquimia.

Teniendo en cuenta todo ello, no es de extrañar que, en sus respuestas a los jueces episcopales, fray Juan reconociera abiertamente, sin el menor temor a que ello cuestionara sus buenas intenciones, haber sido capaz de fabricar plata por sus propios medios:

Preguntado si ha hecho nunca la piedra filosofal, respondio que de las tres piedras, que son animal, vegetal y mineral, probo a vuelta de Nabidad proxime pasada a hazer la mineral en poca cantidad [...] y saco una tabletilla [...] y le salio muy galana plata $^{54}$.

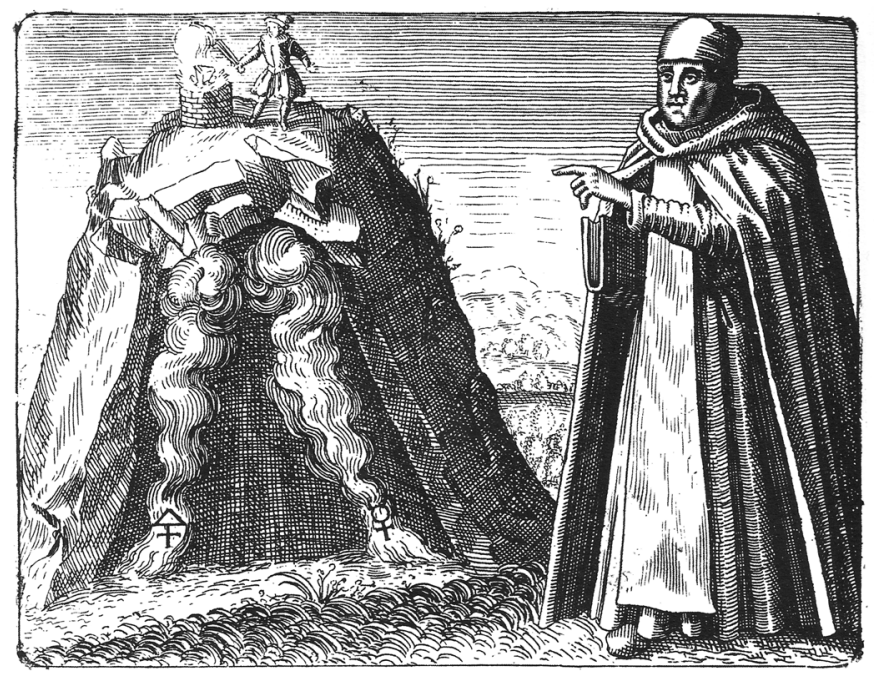

Emblema que ilustra el célebre comentario de Santo Tomás de Aquino al libro Metereologica de Aristóteles, donde se habla de la generación de metales a partir de la mezcla de dos vapores: Azufre y Mercurio. En Michael Maier, Symbola aureae mensae, Fráncfort, 1617.

El fraile estaba completamente convencido de que, después de toda una vida en pos de la famosa piedra, tras haber arriesgado en el empeño su salud, su reputación y buena parte de sus medios, había conseguido al fin transfor-

54 Proceso contra fray Juan, vol. I, fol. 73r. 
mar a voluntad cualquier metal en plata. Tal convicción aparecía claramente constatada en uno de los cuatro cuadernos que le fueron requisados por los jueces episcopales. A pesar de la dificultad del lenguaje alquímico en general, se trata del más explícito de los manuscritos pertenecientes al monje, por estar dirigido al hijo de su hermana, su sobrino Jerónimo Rubio, a quien consideraba su más directo heredero. En el primer capítulo del breve tratado dedicado al joven, el fraile expresaba sus objetivos abiertamente:

Es hora de saber que es la piedra filosofal, tras la que andan los filosofos, y de quien tantas cosas se han escrito y nunca declaran la materia de que se hace ni el modus faciendi, sino solo por enigmas y figuras, como sea verdad que es opus mulierum et ludus puerorum. La razon que dan para esto es que obra tan preciosa y tesoro tan estimable, don de Dios tan subido, no es razon que sea entendido por gente mesera e ignorante, porque si muchos lo supiesen, ya no seria en quien estuviese estimada y preciosa, ni el oro se estimaria por oro, ni la plata se estimaria por plata [...] Y asi le cargo a mi heredero la conciencia no venga este secreto a manos de nadie, sino del hijo que viere que mas prudente le sale. Pues, porque la muerte esta in ianuis y me siento viejo y no se si tendre lugar de comunicar tanto bien como el Señor me ha comunicado, al heredero de la casa de mi padre, llamado Jeronimo Rubio, determino dexalle en escripto con claridad y sin enigmas el como y de que manera y de que se hace la piedra filosofal ${ }^{55}$.

Unas páginas más adelante, tras varios consejos referidos a la búsqueda de un aposento secreto y adecuado, de los materiales idóneos, así como de los medios económicos y contactos necesarios, en medio de la detallada descripción de las diversas técnicas (fijación, coagulación, destilación, proyección, etc.) destinadas a alcanzar el objetivo deseado, fray Juan incluía un significativo párrafo que da fe de la satisfacción que él mismo sentía acerca de sus logros:

Solo he sido en esta ciudad de Zaragoza el que ha salido con la victoria de hacer plata, que la vispera de Todos Santos fue examinada en la plateria de esta ciudad y fue dada por buena plata, y labrada y vendida y martillada, y tirada y tocada y en todo examinada, y nadie otri ha salido con tan buena como la mia ${ }^{56}$.

¿Podemos deducir de dicha confesión que, efectivamente, el fraile era culpable del crimen de que se le acusaba? En principio, una cosa era fabricar «plata», y otra cosa diferente utilizar dicha «habilidad» para defraudar al erario público acuñando moneda a título particular. En cualquier caso, ya fuera

55 Proceso contra fray Juan, vol. I, 455r.

56 Proceso contra fray Juan, vol. I, fol. 467v. 
por la dificultad intrínseca del caso o por la benevolencia de la justicia episcopal, la culpabilidad o inocencia del reo nunca llegó a determinarse. La solemne, pero sobre todo, prudente sentencia con que se dio fin al largo proceso de tres años, así lo demuestra ${ }^{57}$. Desde nuestro actual punto de vista, lo más interesante de la historia es el hecho de contar con dos versiones de los hechos totalmente opuestas. Según la primera de ellas, fray Juan era un avisado falsificador de moneda que, guiado por la necesidad de socorrer a su familia, no había reparado en medios hasta salirse con su objetivo. Según la segunda versión, el fraile había caído en la trampa de un desaprensivo, siendo completamente inocente de los cargos de que se le acusaba. Del engaño propio al ajeno, y de éste al desengaño, fuera cual fuera la verdad del asunto, resulta inquietante seguir el desarrollo de los dos relatos contradictorios y comprobar cómo ambos presentan una congruencia interna impecable.

No es éste el momento de detallar ambas versiones que, como dos ríos paralelos, discurren a lo largo del dilatado proceso, haciéndonos dudar de la posibilidad de llegar a una conclusión definitiva acerca de la culpabilidad del reo. Cuando escuchamos las razones de los acusadores, nos convencemos de que, en efecto, fray Juan fue quien acuñó los cincuenta y tres reales de a ocho falsos que el jurado de Calatayud encontró en la pequeña localidad de Ibdes y que fueron el motivo que desencadenó las acciones judiciales contra el reo y su familia. No obstante, cuando escuchamos los argumentos esgrimidos por el abogado defensor, a pesar de no contar con ninguna prueba decisiva, experimentamos un repentino cambio de parecer: las certezas de los acusadores empiezan a desvanecerse y nos sentimos inclinados a confiar en la inocencia del anciano fraile.

57 La sentencia del proceso, dada el 4 de mayo de 1596, decía así: «Christi Nomine Invocato [...] Fallamos que el dicho procurador fiscal no probo bien su yntinçion conforme probar le combenia para poner al dicho reo la pena ordinaria estatuida en derecho contra los que hazen moneda falsa [...] Pero, atendido que del cargo que se le haze y de lo que se a probado contra el queda muy indiçiado de haver cometido el delito de que esta acusado, sin embargo de la defensa que ha dado, por lo qual pudieramos ponerle muy graves penas, mas usando con el de misericordia por su mucha edad y considerando que a estado preso cerca de dos años, le condenamos a otros dos años de carçel, la qual tenga en el monasterio donde tomo el avito, o en el que le señalare el Padre Reverendissimo General de su Orden. Y que, acavados los dichos dos años, no pueda salir en manera alguna fuera del ambito y clausura del dicho monasterio. Y le privamos de boto atibo y pasibo, y que no pueda tener en su orden offiçio alguno por todos los dias de su vida, ni en su çelda erramienta ni instrumento alguno con que pueda fazer alquimia u otro genero de fundizion. Y que en todo el tiempo que estuviere en la carçel, a mas del offizio y oras divinas a que ya esta obligado, reçe todos los lunes el offiçio de muertos, y los miercoles el cantico grado, y en los sabados el offiçio de Nuestra Señora. Y le condenamos en las costas procesales cuya tasacion nos reservamos.» ( Vid. proceso contra fray Juan, vol. II, fols. 14v y 15r). 


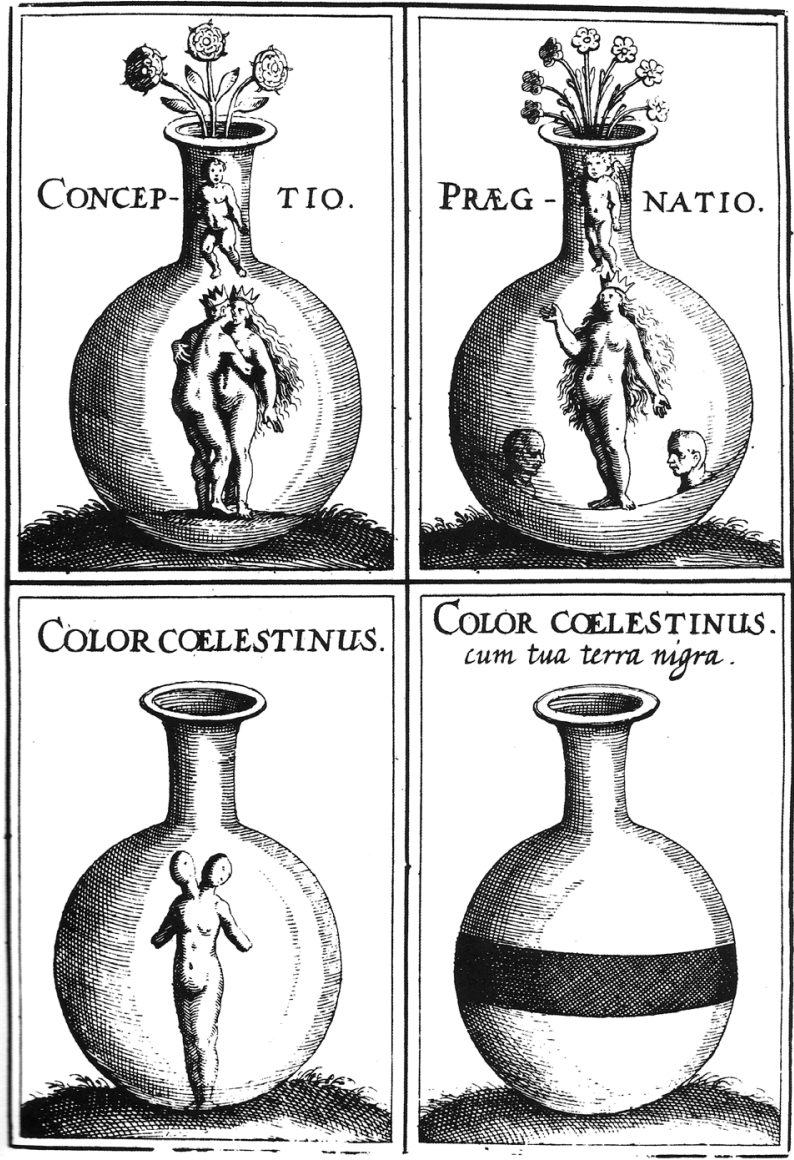

La unión sexual de los principios purificados trae consigo el embarazo y, posteriormente, la disolución y la oscuridad. En Johann Daniel Mylius, Anatomia auri, Fráncfort, 1618.

La tentación de exculpar al protagonista de la historia (o historias, en plural) se acrecienta en nosotros, como espectadores cada vez más implicados, al hacernos conscientes del resentimiento acumulado de que eran objeto fray Juan y su familia por parte de quien había sido responsable de iniciar el largo proceso. Según el procurador arzobispal encargado de la defensa del reo, el jurado de Calatayud que presentó la primera acusación era «enemigo declara- 
do ${ }^{58}$ del marido de la hermana de fray Juan, lo que lo llevó a actuar con «grandissimo rencor y mala voluntad» contra él y su familia, incluido el fraile. El motivo de la animadversión entre los dos hombres se remontaba a muchos años atrás, y tenía que ver con ciertas discusiones acerca del arrendamiento de un molino que el cuñado del fraile había impedido efectuar en varias reuniones del concejo, perjudicando los intereses del jurado. Según el abogado defensor, el estado emocional del jurado (su «rancor y pasión») justificaba plenamente su deseo de venganza que lo había llevado a utilizar todos los medios a su alcance para hundir a su oponente.

A partir de ahí, como en un juego de espejos, la argumentación del abogado defensor giraba, una vez más, en torno al concepto de lo falso. En perfecta simetría respecto a la primitiva acusación de falsificación presentada contra el fraile, el contrarreflejo de la apología esgrimida por su abogado pretendía mostrar que se trataba de una «falsa relación» llena de «malicia»; y que para ello el principal acusador se había valido de «falsos testigos» y «falsas deposiciones». Con los mismos argumentos de quienes pretendían determinar la diferencia entre los verdaderos y falsos alqumistas, el procurador de la defensa fundamentaba la supuesta falsedad de los testigos acusatorios en su mala vida, esto es, en la inmoralidad de sus actos (asesinato, amancebamiento, etc.), de ahí la nula credibilidad que debía prestarse a sus afirmaciones.

Tratándose de un juicio contra un «monedero falso», otro tipo de pruebas más tangibles se presentaron para abonar la «inocencia» del fraile. En este sentido, el testimonio de varios plateros resulta elocuente, porque nos ayuda a entender no sólo ciertos aspectos particulares del caso, sino también hasta dónde llegaba el grado de intervención en el mundo natural considerado admisible en la época. De acuerdo con la mayoría de los plateros interrogados, fray Juan no había podido fabricar moneda con los instrumentos que poseía, pero sí «plata legítima»o, al menos, admitida como tal.

Las operaciones de los alquimistas, con su pretensión de imitar, completar e incluso competir con lo creado ponían de manifiesto más que ninguna otra actividad humana el eterno debate entre naturaleza y arte: ¿hasta qué punto la naturaleza era perfeccionable por el hombre? ¿Hasta qué punto el arte, en tanto que artificio, no era al fin y al cabo un engaño diabólico, una burda imitación de lo divino? ${ }^{59} \mathrm{Si}$ alguna conclusión puede derivarse de este proceso es la imposibilidad de trazar una frontera entre una alquimia «verdadera» (aso-

58 Proceso contra fray Juan, vol. II, fols. 50 y ss.

59 Vid. Newman, W.R. (2004), Promethean Ambitions. Alchemy and the Quest to Perfect Nature, Londres, Chicago, The University of Chicago Press. 
ciada al idealismo del fraile) y una «falsa» (basada en sus intereses materiales): ambos aspectos se entremezclan, inseparables de su personalidad y de sus circunstancias. La alquimia de fray Juan no constituía una disciplina espiritual heroica en pos de un ideal inalcanzable o, por el contrario, una quimera absurda, basada en creencias supersticiosas. Un error todavía mayor sería calificarla de engaño deliberado o de simple estafa, teniendo en cuenta la vehemente dedicación del fraile a sus experimentos, su intensa convicción interior y su indudable interés en los aspectos teóricos del arte.

La alquimia de fray Juan aunaba una fe inquebrantable en la posibilidad de colaborar en la obra divina con el empeño, no menos persistente, de acrecentar la hacienda de sus herederos. Ambas facetas eran compatibles para él, y no le causaban el menor escrúpulo de conciencia. Convencido de su capacidad para enriquecer a su empobrecida familia, el monje se refería en uno de sus cuadernos a «la grande ganancia de esta multiplicación» ${ }^{60}$, esto es, a la feliz coyuntura del alquimista experimentado, consistente en poder duplicar cada día la riqueza conseguida la jornada anterior. Como en el cuento de la lechera, el fraile soñaba despierto y transmitía sus fantasías a su sobrino explicándole cómo, en menos de un mes, cien reales podían transformarse fácilmente en seiscientos setenta y ocho mil cuatrocientos, siempre que pudiera venderse la plata fabricada al ritmo deseado ${ }^{61}$.

Lo más probable es que fray Juan nunca llegara a fabricar moneda directamente, pero lo que sí es claro es que intentó conseguir la máxima cantidad de ésta, aunque fuera con el propósito de favorecer a terceras personas. A sabiendas de que tal habilidad debía mantenerse en secreto, en uno de sus cuadernos se dirigía a su sobrino sin ambages con las siguientes palabras:

Estais sujeto a que cualquiere hijo de ruin os acuse ante el Virrey o gobernador de la tierra o reyno donde esteis. Y aunque en esto hazer no hay pecado ninguno, ni os

60 El capítulo noveno del cuarto cuaderno, dedicado por el fraile a su sobrino, llevaba como título: «De la grande ganancia de esta multiplicacion». Proceso contra fray Juan, vol. I, fol. 469r.

61 Fray Juan pretendía transmitir a su sobrino su convicción acerca de la posibilidad de doblar cada día el dinero adquirido el dia anterior, siguiendo una estricta progresión geometrica que, de forma poética, expresaba como sigue: «Oid con atencion [...]: Entrais con caudal el primero dia de la semana de cien reales, y haceis una proyection de Luna sobre el Venus, y acostaros con doscientos reales. El martes entrais por la mañana con doscientos reales y anocheceis con cuatrocientos. El miercoles entrais con cuatrocientos y cenais con ochocientos. El jueves amaneceis con seyscientos, y reposais a la noche con tres mil y doscientos. El sabado despertais con tres mil y doscientos, y dormis con seis mil y cuatrocientos...». Proceso contra fray Juan, vol. I, fol. 469v. 
castigaran, porque cualquiera puede hazer de su capa un sayo, y en mi casa puedo hacer lo que se me antojare como no sea moneda, empero, por cuanto viene y podria venir daño al rey y aun a la republica [...], para remedio de esto hase de procurar tener $[\ldots]$ unos moldes de cucharas, o de otra cosa que imprima pieza ya hecha, porque vendiendo vos vuestra plata en pieza ya hecha, encubris ser vos el autor della ${ }^{62}$.

Ciertamente, convertir una capa en un sayo constituía una tarea irrealizable, dado el menor tamaño de aquélla. Pero convertir cualquier metal innoble en «plata de ley» mediante el arte de la alquimia, todavía era posible, aunque arriesgado, a finales del siglo XVI. La popular expresión «cada uno es libre de hacer de su capa un sayo» se refería, y continúa refiriéndose todavía hoy, a la capacidad de cada individuo para actuar al margen de toda norma impuesta desde fuera. Más o menos culpable, más o menos inocente, con pecado o sin él, fray Juan representa un buen ejemplo de la ambigüedad e indefinición de muchos alquimistas de su época que, como él, se afanaron en alcanzar el secreto de la piedra filosofal al tiempo que procuraban remedio a sus necesidades.

Recibido: 8 de febrero de 2010.

Aceptado: 20 de septiembre de 2010.

62 Proceso contra fray Juan, vol. I, fol. 468r. 